\title{
Problems of the Roma families: LOCATION ORECHOV DVOR IN NITRA
}

\section{Denisa Selická, Monika Štrbová, Marcela Šarvajcová}

\begin{abstract}
In our contribution we deal with selected problems of the Roma in the Slovak society on the example of the Roma who live in the segregated location of Orechov Dvor in Nitra. These problems are characteristic for all segregated housing in Slovakia where the Roma live. This is a problem of substandard housing, inadequate education, almost 100 percent unemployment, and from the perspective of the majority inadequate leisure time too.
\end{abstract}

Key words: Roma people, housing, education, unemployment, leisure time.

\section{Problémy romských rodin v lokalitě Orechov Dvor v Nitře}

\begin{abstract}
Abstrakt
V našom príspevku sa venujeme vybraným problémom Rómov v slovenskej spoločnosti na príklade Rómov, ktorí žijú v segregovanej osade Orechov dvor pri Nitre. Tieto problémy sú charakteristické pre všetky segregované obydlia na Slovensku, kde žijú Rómovia. Ide o problém nevyhovujúceho bývania, nedostatočného vzdelania, takmer 100percentnej nezamestnanosti a z pohl'adu majority aj neadekvátneho trávenia vol'ného času.
\end{abstract}

Klúčové slová: Rómovia, bývanie, vzdelanie, nezamestnanost', trávenie vol'ného času. 


\section{Introduction: a description of the site}

The location Orechov dvor is located in the cadastral area of Nitra-Horné Krškany. It is a peripheral part of the cadastral area of Nitra, located outside of the main communication access to it. The city of Nitra in 2005 - in the first phase it built apartment buildings in this location - 36 housing units in order to solve the outstanding problems of socially disadvantaged residents of the city of Nitra. The second phase of the construction was realized with totally of 25 residential units in 2009.

The city of Nitra wanted at least partially prevent the eviction of socially disadvantaged residents of the streets because of the long-term unpaid rent by building a complex of residential houses. The area, on which the apartment buildings are built, with a total of 61 one-bedroom and two-bedroom apartments, adjacent to the former area of agricultural production company - Orechov. The functional design of a building is based on apartment buildings that form the compositional monobloc housing positioned around the communication area - an open staircase. The heating system of these buildings was originally provided by electricity and for the preparation of food the facilities were provided by installing solid fuel cookers. Sewage disposal is provided by collecting in cesspits and then transported to the sewage disposal plant. This location is connected to urban road networks - to Jakub Hašek Street by tertiary roads and to the national road Nitra-Cabaj. The access road to the location is a field road, which was covered by stone grit to facilitate access for residents of the community. The nearest bus stop is about $2 \mathrm{~km}$ far away from the residential houses.

As to 31. 5. 2014, 353 socially reliant citizens, mainly from the Roma ethnic group (289), lived in the segregated location Orechov Dvor. 164 of them were men and 189 women (according to unofficial data, twice as many people lives there). The residents are without stable income, long-term unemployed, with low education, dependent on social benefits in material need. They have been placed to this location by the city of Nitra gradually since 2005, after they became homeless. They were evicted by residential companies onto the street because of their long-term economic insolvency of paying rent. Most of the residents are registered with the Office of Labor, Social Matters and Family. However, there are also families which are not in any official registry. Opportunities for improving their economic situation of these families are very limited.

The most visible problems in the area Orechov Dvor include: the life of the people at risk of poverty, a high level of unemployment and dependence on the system of state social benefits, neglect of compulsory school attendance, lack of hygiene in households, improper financial management in the households, lack of care for minors and primary needs of children, coexistence with the majority society. 


\section{Housing}

The peripheral status of the Roma in society can be understood as a peripheral role in the mental or physical sense. In physical sense we are referring to housing of the Roma. This segregation by residence has strengthened over the past 20 years. Nowadays $70 \%$ of the Roma live in an environment where Roma families live exclusively or mainly, and another $20 \%$ of the Roma live in an environment where there is the same ratio of non-Roma and Roma families.

Housing in a suburb is one of the main things which the Roma living at Orechov Dvor would change in their lives. They are not satisfied with the fact that they live far away from the city center. This type of housing complicates the life of the Roma in particular because they do not have nor groceries shops, neither nursery nor schools nearby. Just because in this part there is no bus stop, the Roma have to walk several kilometers to the nearest bus stop. Life in a segregated part of the town directly affects the quality of life and opportunities or access to goods and services. According to the statements of the Roma, this is also the reason why children do not attend school and adults do not attend work regularly.

Housing is generally very sensitive for the Roma from the settlement; they realize that the city evicted them because they did not pay rent and destroyed housing units but they feel aggrieved that they live in this environment. They do not blame themselves and they also think that they do not deserve housing like this. On the other hand, they admit that housing in the city is unavailable for them because of their poor social situation.

\section{Figure 1}

Surroundings of Orechov Dvor

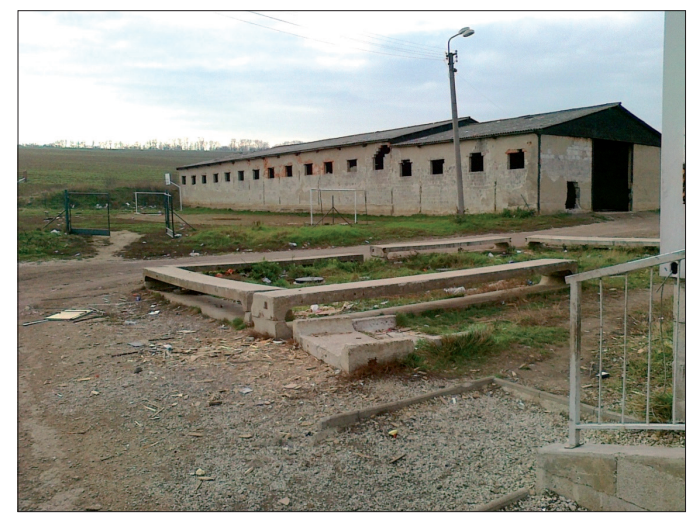


Besides the segregated type of housing, it is very important to talk about multi-generational housing with the Roma, which is typical for this population group. While anybody from the respondents does not prefer segregation, everybody is identified with multigenerational housing and they would not change this way of living. Women use to live with their parents-in-law, partners and children most often in one and two-bedroom apartments. Even if they had opportunity to move into another housing, they would choose living together. According to their subjective statements (as well as to the statements of nurses operating in the settlement), their apartments have standard equipment, mostly are one or two-bedroom apartments with kitchen, bathroom and toilet. The problem is that the apartments are small for the families; this greatly reduces the quality of housing, parents and children suffer from a lack of privacy. In such an environment we can talk about very substantial reproduction of negative social phenomena.

The issue of housing is complex and difficult, because it encompasses a number of sub-issues: poor housing conditions, both in rural communities and also in urban areas; non-payment and subsequent eviction of defaulters; ghettoisation; overcrowding of houses; poor hygiene standards. A solution could be the construction of social housing of a lower standard. There are terraced houses for families, which are generally sponsored by state funds and municipalities.

In the context of this type of housing we can talk about multi-space building, in which the standard is a kitchen and sanitary facilities as well as a living room and in some cases an extra room. Uhl (2006) subjects the housing policy of municipalities to criticism. Municipalities are excluding socially disadvantaged into the category of less expensive housing. According to Uhl - within the maximum cost-effectiveness, a village concentrates such persons into a single location, which thus turns into a ghetto or they move them outside of the village by certain steps, mostly to smaller communities where there a ghetto also arises. This means that the ghetto is thus therritorialisated and preserved, and its residents adapt to its conditions so that they are losing effort to anchor outside of the ghetto. And as we have mentioned, segregated living quarters are under risk of social exclusion. We think that these segregated dwellings are "time bombs".

\section{Education}

Upbringing and education of Roma pupils are the basic prerequisites for successful solution of issues occurring in the Roma community. Targeted upbringing and education create preconditions for a gradual change in the value system of Roma families so that education would become an accepted value for the Roma and also a prerequisite for success in dealing with social and economic problems. Problems of the Roma population are often associated with a lack of education, which causes other problems 
characteristic for this ethnic group, namely unemployment, poor housing conditions, crime and other social-pathological phenomena. Roma pupils are - as soon as they start attending the school - often considered intractable or incapacitated. A Roma child that grew up in freedom, liberty, without obvious rules, orders or prohibitions suddenly has to adapt - from one day to another - to completely different conditions and requirements of the new environment. Teacher, educator or social educator should seek primarily to help Roma children with the process of adaptation in the school environment. Reforms or the introduction of the all-day education system for Roma students have already their own history.

Our research also shows that major obstacle to successful operation of the school effect on a Roma child is low appreciation of education in the value system of Roma families. Qualitative analysis concerning Orechov Dvor in Nitra shows that the older generation is almost completely illiterate, according to the middle generation it is possible to conclude that their parents had no interest on their education and they thought that attending school was waste of time and caused organizational and financial problems. Only 2 in 10 surveyed Roma women could read and write. It is important to note that the social environment plays a key role in relation to education, and children come to school without mastering basic skills or habits conditioning their success at school because of parental illiteracy.

The Roma women in the discussion expressed the importance of education for their children (note: under the term of "education" they understand especially the ability to read and write), they care about their children's school attendance, but it is questionable how much they can motivate their children. It is possible to talk about a certain shift in the perception of education because no one cared about education of the middle generation but the middle generation already cares about school attendance of their children.

The interviewed Roma women are trying to provide some learning space for their children, care about their children's ability to read and write, they expect boys to graduate from a vocational school. The middle generation recognizes the importance of education for finding a job. By the completion of compulsory schooling they mostly understand the ability to read, write, and the only possibility how to become an apprentice.

It is possible to talk about the significance and importance of education in contemporary society from the perspective of the Roma just simplistically (complete secondary or university education is strange for children). Girls are still perceived differently from boys in the context of education. Parents do not expect their girls to get apprentice. At that age girls should be already prepared for marriage. They see this as priority.

The following table shows how many discussed children attend school and what would they like to be in their lives, what would they like to do as apprentices (what would they like to do for living). 
As we can see, most of the children are attending school, although we cannot say that they have clear ideas about their labor-market exposure. Answers of the question about what would they like to be were spontaneous, it is not possible to expect children to say that they would do everything to achieve the apprenticeship. Half the children openly said that they do not want to do anything. They answered supplementary questions whether they wanted at least go to sell things ("to scalp") as their fathers that they would like to go to Poland to sell things. According to their statements it is clear that they do not care about their future and in their understanding education had nothing to do with success in the labor market. The second half of the children had a somewhat clearer picture about their future. This was particularly case of children which enjoy being at school and they attend it with pleasure. We can say that it is possible to see the interest of the parents in education of their children and children's attendance of school, even though half of them are not interested in higher education nor seek an adequate position in the labor market.

Raising children in a Roma family is directly dependent on the way of life in these families. All socialization processes in the Roma family are driven only by institution of family; in the next picture we can see what parents often prohibit to children as well as how children perceive those obligations and prohibitions.

The figure shows that while the parents require attending school and doing their homework from their children, the children do not mention this option by themselves at all. The children do not perceive that they have to do something. Although the parents say that the children have to do homework and learn at home, perhaps they do not show strictly how much they insist on it, not even that it is important for their future.

The results, which have been shown in our research about the relationship and parents' access to their children's education, confirm that there are several fundamental facts that are directly affecting the risk of transmission of poverty in the family and also to possibility of its persistence within a few generations. It is possible to talk about some basic factors, which have a significant influence on the Roma population: education, labor market attachment, family structure, social and cultural capital and the quality of family environment.

\section{Leisure time}

Leisure time of youth can be viewed from two perspectives. On the one hand, it can be a positive element during the formation of personality, it can also develop individuality, interests, or contribute to an active and valuable personal and social life. On the other hand, it may also contribute to deformation of young people's personalities, and negative leisure time can lead to passivity, asocial or antisocial acts. Kraus points out that a vast majority of young people has, wants to have and might have free time but they are not able to use it properly. They are unable to navigate through menus, they 
are clueless in managing their time properly and they also lack necessary information and skills. However, this opens a space for boredom and anti-social activities.

The problem of the undesirable way of spending their free time is that despite of the fact that the amount of leisure time has grown in comparison with the past, young people do not know how to use their leisure time properly. Youth in this case act asocially, antisocially. In society in general, we consider the most serious risks of alcohol, drugs and gambling, which we confirmed by research on Orechov Dvor in Nitra, where the Roma have free time but they do not know how to use it effectively. The parents and their children do not know how to navigate through menus, they lack the basic skills and necessary information. Leisure activities in this settlement are ineffective and sometimes even harmful. The Roma children from the discussion group were aged 12 to 16 years, and all the boys had experience with playing cards for money or with smoking.

Based on theoretical knowledge of leisure activities we can classify leisure time of the Roma from Orechov Dvor as a group, regular with a broad organization. Although leisure time It Orechov Dvor can be classified as social activities that boost the development of social contact and social interactions with friends and family, it is very important to deal with an intensive care about the Roma and lead them in a way they should spend their leisure time effectively. Especially for children of young age, the nurses try to do by their activities - nurses organize camps and trips for children from the zero grade. Due to capacity reasons, however, this way of spending free time will be realized only for a part of the children.

As we mentioned before, the research conducted on Orechov Dvor in Nitra shows that the Roma spend their free time undesirably. The following figure provides a list of possible answers to the question what they do in their free time.

Just because the youngest generation faces playing cards on a daily basis with, it is important to talk about undesirable leisure activities such as pathological gambling or other gambling. In contrast to alcohol or marijuana, there is no direct damage to health by any substance, even though consequences to psyche are often similar. There appear to be some psychological problems as distress, fear, fear of creditors but often the beginning of a criminal career.

These problems of the Roma at Orechov Dvor in Nitra are typical for families of uninspiring environment. This is about whether the people involved want to solve it. On the one hand, it is declared that the Roma want to live in accordance with the standards of society, on the other hand, the reality does not indicate it. And of course we need to change the stereotypes of society towards the Roma, and it also is "a long-distance run". 


\section{References}

Jurkovičová, A: Volný čas, jeho aktívne a zmysluplné využívanie ako prevencia sociálno-patologických javov mládeže. In: Mládež a spoločnosṫ. 2010, vol. XVI, no. 3. ISSN 1335-1109

Kraus, B. et al.: Jak žije středoškolská mládež na počátku XXI. století: Výzkum v Královéhradeckém kraji v letech 2000-2003. Hradec Králové: Gaudeamus, 2004. ISBN 80-7041-738-2.

Longauer, V.: Metodologický náčrt vzdelávania rómskych žiakov. In:Vzdelávanie Rómov dnes a zajtra. Zborník referátov z 2. medzinárodnej konferencie konanej 27. novembra 2001v Nitre. Nitra: UKF, 2001. ISBN 80-8050-498-9.

Mušinka, A.: Bývanie Rómov. In: Čačipen pal o Roma. Súhrnná správa o Rómoch na Slovensku. Bratislava: Inštitút pre verejné otázky, 2002. ISBN 80-88935-41-5

Ondrejkovič, P. et al.: Sociálna patológia. Bratislava: Veda: 2009. ISBN 978-80-224-1074-8.

Uhl, P.: Právo a jeho účinky v sociálně vyloučených lokalitách $s$ přihlédnutím k problematice diskriminace a ochrany před ní. In: Hirt, J., Jakoubek, M. (eds.): Romové v osidlech sociálního vyloučení. Plzeň: Aleš Čeněk, 2006. pp. 70-90. ISBN 80-86898-76-8

www.foruminst.sk

www. foruminst/sk/publ/neksz/2003_sk_6.pdf

\section{Contacts:}

PaedDr. PhDr. Denisa Selická,Ph.D.

PhDr. Monika Štrbová, Ph.D.

Mgr. Marcela Šarvajcová, Ph.D.

Katedra sociológie FF UKF

B. Slančíkovej 1, 94974 Nitra, Slovak Republic

PaedDr. PhDr. Denisa Selická, Ph.D.

She works at the Department of Sociology at the Constantine the Philosopher University in Nitra (Univerzita Konštantína Filozofa v Nitre). She teaches pedagogical disciplines: sociology of education, social pedagogy, social policy. In her scientific and research activities, she deals with intergenerational relationship in family. She is an author of monographs, academic textbooks and scientific studies. She is a member of the Sociological Society at SAV in Bratislava and a member of the Editorial Board of Youth and Society.

\section{PhDr. Monika Štrbová, Ph.D.}

She works at the Department of Sociology at the Constantine the Philosopher University in Nitra (Univerzita Konštantína Filozofa v Nitre), is the head of the Department. She teaches pedagogical disciplines: social pathology, sociology of family, sociological theories. In her scientific and research activities she deals with intergenerational relationships in Roma family. She is an author of monographs, academic textbooks and scientific studies. She is a member of the sociological society at SAS in Bratislava and a member of the Editorial Board of the Journal of Youth and Society.

\section{Mgr. Marcela Šarvajcová, Ph.D.}

She works at the Constantine the Philosopher University in Nitra (Univerzita Konštantína Filozofa v Nitre) as an assistant professor. She teaches pedagogical disciplines: research methods (quantitative and qualitative), sociological theories and sociology of poverty. In her scientific and research activities he deals with intergenerational relationships in Roma family. She is an author of monographs, academic textbooks and scientific studies. She is a member of Sociological Society at SAV in Bratislava. 